\title{
Synestezyjna poetyka lektury i przekładu: Barthes - Nabokov - Robinson
}

\section{Zuzanna Kozłowska}

Kontakt z literaturą, jak każda forma kontaktu, rozgrywa się zawsze na rozpiętości przyjemnego i nieprzyjemnego. Czytanie oraz tłumaczenie to czynności angażujące doświadczające ciało - stany somatyczne, sensualne oraz seksualne. A jednak przyjemnościowy potencjał literatury, zasznurowany w sztywnym gorsecie nowoczesnej teorii, nie przedostał się w sposób jawny do literaturoznawczej refleksji. Dopiero prowokacyjne projekty erotyzacji teorii literatury, formułowane przez Susan Sontag, a następnie Rolanda Barthes'a, otworzyły ją na realność literackich rozkoszy oraz przyjemności. Jako nieodzowne właściwości obcowania z tekstem, cielesne repulsje i spełnienia stają się współcześnie pełnowartościowymi formami estetycznego doświadczania - wymiarami w pełni zrestaurowanego aisthesis: estetyki jako czucia. Barthes'owska rozkosz (jouissance) oraz przyjemność (plaisir) ${ }^{1}$ czytelnicza uwolniły skrępowane ciało teorii:

Nienazywalność i niewyrażalność rozkoszy [...] wymierzona zostanie zwłaszcza przeciw egzegezie, zmysłowość czytania stanie naprzeciw dyktatury sensu, frywolność zadrwi z inteligibilności. Ciało odziane przez Barthes'a jedynie w przezroczysty woal skandalu spełni w tym przypadku iście rewolucyjną rolę - zafunduje teorii interpretacji rodzaj terapii wstrząsowej, wprowadzając w czyn wcześniejszy, równie prowokacyjny (choć nie zrealizowany) projekt Susan Sontag².

\footnotetext{
${ }^{1}$ Rozumiane, za Barthes'em, jako dwie odrębne jakości (w przeciwieństwie do rozumienia rozkoszy jako intensywnej przyjemności - a więc w kategoriach ilościowych, a nie jakościowych): transgresyjna, aspołeczna rozkosz oraz społeczna, familiarna przyjemność.

${ }^{2}$ A. Burzyńska, Ciało w bibliotece, [w:] tejże, Anty-teoria literatury, Kraków 2006, s. 245.
} 
Barthes'a skandaliczna Przyjemność tekstu z 1973 roku to nie tylko tematyzacja rozkoszy czytania, to także jej demonstracja. Tekst Barthes'a nie tyle wykłada, co uobecnia erotyczne doświadczenie: przedmiot zawłaszcza język, zajmując miłosną gorączką styl Barthes'owskiego manifestu. Odsłaniając „kokieteryjność” ${ }^{3}$ literatury, Roland Barthes żongluje wielomodalnymi metaforami sensualnymi, angażując oraz splatając zmysły w erotycznym - synestezyjnym uścisku: słowa smakują, dotykają, przyprawiają o mdłości, rumienią się, podniecają. Synestezja okazuje się niebagatelnym argumentem Przyjemności tekstu, gdyż w sposób wyjątkowo jednoznaczny uwypukla substancjalność języka, stanowiącą nieusuwalny próg erotyzacji tekstu: „Erotyka czy cielesna przyjemność doświadczeń czytelniczych wynika ze zogniskowania na materialności tekstu"4. Synestezja jako proceder retoryczny sensualizuje język, wskazuje na jego skomplikowaną poli- oraz intersensualną naturę. Na materialność języka, jako „wielowymiarowe pojęcie, obejmujące to wszystko, co współtworzy fizyczny kościec tekstu”, składają się zarówno brzmieniowe jakości mowy, wizualne właściwości typograficzne pisma, jak i mniej oczywiste składniki percepcji tekstu, takie jak zapach świeżego druku czy tekstura papieru bądź ekranu. Jak zauważa Tong-King Lee: „Twórczość literacka oraz przekład są i zawsze były sprawą materialną i wielomodalną" chociażby ze względu na „kinestetyczny wymiar pisania, kolor i typograficzne właściwości słów na stronie bądź ekranie, dźwięk głosu w przypadku tłumaczenia ustnego"7. Niniejszy artykuł tezę tę radykalizuje, wskazując na synestezyjne odczuwanie języka jako tryb estetycznego (w całym tego słowa etymologicznym znaczeniu) doświadczania tekstu, rozpiętego na nielinearnej siatce rozkoszy, przyjemności, odpowiedniości, anestetycznej nudy, somatycznej robotyzacji oraz idiosynkrazji. Synestezja zdaje się zasilać swoistą poetykę lektury i przekładu analizowanych autorów.

Synestezja jest u Barthes'a zasadą czytelniczej przyjemności czytania - przyjemności hiper- oraz intersensualnej, w której zbliżeniu ulegają rozmaite wrażenia zmysłowe. Źródłem gustatorycznej przyjemności czytelniczej jest taktylno-kinetyczna wrażeniowość odbioru: „W opowiadaniu smakuje mi zatem nie sama treść i nawet nie jego struktura, ale ślady paznokciem, jakie zostawiam na powierzchni: tu przebiegam, tu przeskakuję, tu podnoszę głowę, tu zapadam się w otchłań". Wzrok przebiegający po tekście przekłada się na tekstu dotykanie, na przebieganie (palcami, wzrokiem, ruchem głowy i dłoni) po jego ciele; wreszcie: na jego smak. Tekst jest ciałem, przestrzenią ciała (rozpiętością skóry), w którą można się zapaść, którą można przebiec, przeskoczyć, wznieść się nad nią. Tekst jest ciałem i czytanie jest cielesne:

Skoro tekst ma ludzki kształt, czy jest figurą, anagramem ciała? Tak, lecz naszego ciała erotycznego. Przyjemności tekstu nie da się sprowadzić do jego gramatycznego (feno-tekstualnego) funkcjonowania, bo i przyjemność ciała nie sprowadza się do potrzeb fizjologicznych ${ }^{9}$.

\footnotetext{
${ }^{3}$ R. Barthes, Przyjemność tekstu, Warszawa 1997, s. 11.

${ }^{4}$ T.-K. Lee, Translation, materiality, intersemioticity: Excursions in experimental literature, „Semiotica” 2014, nr 202, przeł. Z. Kozłowska, s. 347.

${ }^{5}$ Tamże.

${ }^{6}$ Tamże.

7 Tamże.

${ }^{8}$ R. Barthes, Przyjemność tekstu, s. 19.

${ }^{9}$ Tamże, s. 22.
} 
Synestetyczna „patyna spółgłosek, lubieżność samogłosek” ${ }^{10}$, „materialność, zmysłowość oddechu, chrypy, miękkości warg"11 staje się fundamentem czytelniczej oraz wytwórczej rozkoszy tekstu. Piętrząca się metaforyka intersensualna pełni w Przyjemności tekstu funkcję donośną: doświadczanie międzyzmysłowe staje się podstawą rozumienia języka jako tkanki o określonej teksturze oraz potencjale olfaktorycznym i kinetycznym, jako materii o właściwościach smakowych oraz wizualnych („słowa błyszczą"12, są barwne), a także - przede wszystkim - jako materiale dźwiękowym, wybrzmiewającym w mówiącym „pysku” ${ }^{13}$ : „niech głos, niech pisanie będą świeże, swobodne, obślinione, drobnoziarniste i drgające jak pysk zwierzęcia"14. Intersensualność jest w tak projektowanej lekturze pomostem pomiędzy ciałem a językiem ${ }^{15}$. Synestezyjnie doznawane słowo „pada niespodziewanie i soczyście” ${ }^{16}$. Dzięki synestezyjnemu doznaniu materialności języka podmiot mówiący sięga w artykulacji głębi ciała, głębi jego przyjemności - by osiągnąć tekstualną rozkosz: „grzechocze, trzeszczy, pieści, trze, tnie: szczytuje"17.

Przyjemność tekstu jest przyjemnością intersensualnego doświadczania substancjalnej tkanki języka, eksploracją jego wrażeniowego potencjału. Jeśli tekst jest erotycznym ciałem, to język jest tego ciała budulcem, jego krwią, mięśniami, skórą. Biologicznie, materialnie pojmowany język jest źródłem ruchu, a ściślej: chorobliwej ekscytacji - idiomatycznej palpitacji („palpitacje [...] wyrażeń"18), słownego wytrysku („bryzg słów”19), aż po stylistyczny zawał serca (,atak serca”20). Język jest też materią jadalną, słowa możemy smakować („Smakuję królestwo formuł” ${ }^{21}$ ) bądź przełykać z obrzydzeniem (,język przełknąć bez mdłości”22). Barthes'owska synestezja, wpisująca się w szerszy projekt „rehabilitacji zmysłowego postrzegania”23, jest dla badacza narzędziem aplikowanym świadomie jako figura cielesności, zmysłowości oraz przyjemności. Barthes'owska synestezja jest zatem synestezją operacyjną, retoryczną, stosowaną konsekwentnie jako funkcja pewnego projektu.

\footnotetext{
${ }^{10}$ Tamże, s. 98.

${ }^{11}$ Tamże, s. 98-99.

${ }^{12}$ Tamże, s. 62.

${ }^{13}$ Tamże, s. 98-99.

${ }^{14}$ Tamże.

${ }^{15}$ Por. rozumienie synestezji Anny Łebkowskiej: A. Łebkowska, Jak ucieleśnić ciało: o jednym z dylematów somatopoetyki, „Teksty Drugie” 2011, nr 4.

${ }^{16}$ R. Barthes, Przyjemność tekstu, s. 62.

${ }^{17}$ Tamże, s. 98-99.

${ }^{18}$ Tamże, s. 76.

${ }^{19}$ Tamże, s. 13.

${ }^{20}$ Tamże, s. 76 .

${ }^{21}$ Tamże, s. 42.

${ }^{22}$ Tamże, s. 64.

${ }^{23}$ Por. C. Oboussier, Synaesthesia in Cixous and Barthes, 〈http://core.ac.uk/download/pdf/17407.pdf〉 [dostęp: 20.05.2017], s. 115: „Synaesthesia is axial in the intersecting projects of Cixous and Barthes to rehabilitate sensory perception [...] which, in turn, is integral to a wider concern to redefine knowledge".
} 
Odmiennym świadectwem synestetycznej wrażliwości tekstu jest intersensualna proza Vladimira Nabokova, autora obdarzonego percepcyjną postacią synestezji. Znane są rozmaite typy synestezji związanej z językiem ${ }^{24}$ : taktylne czucie pisma, barwne litery, smakowanie słów, słowa wonne, mowa postrzegana wzrokowo ${ }^{25}$, a nawet personifikacje grafemów (tj. atrybucja płci oraz cech osobowościowych literom alfabetu oraz cyfrom). Vladimir Nabokov, synesteta typu grafem-kolor (barwne pismo), fonem-kolor (barwna mowa) ${ }^{26}$ oraz prawdopodobnie także grafem-personifikacja ${ }^{27}$, starannie przeżuwał słowa, dokładnie odmierzając ich wagę, kształt oraz brzmienie zarówno w twórczości oryginalnej, jak i (auto)przekładowej.

W The Art of Translation z 1941 roku Nabokov bezlitośnie rozprawia się z translatorskimi omyłkami, przekładową arogancją i ignorancją, jednocześnie eksponując i eksplikując własny kunszt tłumaczeniowy. Nabokov ujawnia swą ars translatoria, omawiając aporie przekładu inicjalnego wersu Puszkinowskiego wiersza Я помню чудное мгновенье ${ }^{28}$, który autor Bladego ognia przytacza jedynie w zapisie fonetycznym: „Yah pom-new chewed-no-yay mg-no-vain-yay”29. Próba ukucia dźwiękowego ekwiwalentu rosyjskiego wersu za pomocą sylab języka angielskiego wskazuje na uprzywilejowanie warstwy brzmieniowej tekstu w tłumaczeniu. Nabokova opis sensualnych właściwości Puszkinowskiego wersu pełen jest synestezyjnych metafor, będących w istocie odzwierciedleniem percepcyjnej specyfiki utworu w subiektywnym, idiosomatycznym doświadczeniu autora Zaproszenia na egzekucję. Nabokov opisuje swój cielesny odbiór rosyjskiego wersu: jego kojącą, ekscytującą melodię („The melody of the line [...] is to the Russian ear most exciting and soothing”), z pulchnym („plump”), złociście dojrzałym („golden-ripe”) "chewed-no-yay” w samym środku wersu oraz rozsianymi po bokach głoskami „m” i „n”, utrzymującymi wers w przyjemnej równowadze („the «m's» and «n's» balancing each other on both sides"). Zestawiając rosyjski ustęp z jego literalnym tłumaczeniem na język angielski, Nabokov animizuje oraz personifikuje poszczególne wyrazy bądź złożenia wyrazowe Puszkinowskiego wersu: „Yah pom-new” oraz jego angielski literalny odpowiednik „I remember” dokonują „skoku” („plunge”) w przeszłość: głęboko i gładko („deeper and smoother”) w przypadku oryginału, płasko „na brzuch” („flat on its belly”) jak „niedoświadczony nurek” (,inexperienced diver”) w przypadku dosłownego tłumaczenia. Co więcej, w „chewed-no-yay” zawiera się rosyjski „potwór” („«chewed-no-yay» has a lovely Russian «monster» in it”) - ze względu na wspólny źródłosłów wyrazów (чудо́вище; чу́дный). Nabokov pokazuje, że tłumaczenie nie jest prostą substytucją wyizolowanych jednostek systemu językowego; słowa przynależą bowiem

\footnotetext{
${ }^{24}$ Por. aktualizowane dane na stronie S.A. Daya: Demographic aspects of synesthesia, <http://www.daysyn.com/ Types-of-Syn.html> [dostęp: 20.05.2017].

${ }^{25}$ Typ ticker-tape polega na przetwarzaniu słyszanej mowy na zapis graficzny, percypowany wizualnie w przestrzeni pola widzenia synestety.

${ }^{26}$ Por. Na temat synestezji u Nabokova zob. A. Ginter, Vladimir Nabokov i jego synestezyjny świat, Łódź 2016; D. B. Johnson, Synesthesia, Polychromatism, and Nabokov, [w:] A Book of Things about Vladimir Nabokov, red. C. R. Proffer, Ardis 1974; S. Conradt, Vladimir Nabokov Talks Synaesthesia, < http://mentalfloss. com/article/49442/vladimir-nabokov-talks-synesthesia> [dostęp: 30.04.2015]; Nabokov's interview, BBC Television [1962], <http://lib.ru/NABOKOW/Inter02.txt>, [dostęp: 30.04.2015]. Zob. także autobiografię pisarza: V. Nabokov, Speak, Memory: An Autobiography Revisited, New York 1966.

${ }^{27}$ Personifikacje występują w kuriozalnej odmianie synestezji „ordinal-linguistic personification” (porządkowojęzykowa personifikacja).

${ }^{28} \mathrm{~W}$ polskim przekładzie Wiktora Woroszylskiego inicjalny wers brzmi: „Cudowne pomnę oka mgnienie”; w wersji Seweryna Pollaka: „Pamiętam nagłe zachwycenie”.

${ }^{29}$ V. Nabokov, The Art of Translation, „The New Republic” 1941. Wszystkie cytaty Vladimira Nabokova pochodzą z tego źródła.
} 
do ciągów brzmieniowych oraz znaczeniowych, dynamicznie współtworzących sens wypowiedzi. Pozbawione tej intrajęzykowej ciężkości, lądują płasko na banalnym gruncie nieprzyjemnej dosłowności. Słowa Nabokova mają nie tylko kolor, ale i dotykalną formę ${ }^{30}$. Pisanie, tłumaczenie - to stan dotykalny. Przekład - to proces ważenia słów, szacowania ich kształtów, tekstur, barw, ich potencjału kinetycznego, wreszcie: ich wzajemnych, wielopoziomowych związków (etymologicznych, kognitywnych, brzmieniowych). W krytyce przekładu Vladimira Nabokova doświadczana przezeń synestezja kliniczna staje się realnym kryterium smaku, instrumentem krytyki, techniką ewaluacji tłumaczenia.

Kolejnym przykładem synestezyjnej poetyki czytania i tłumaczenia jest Douglasa Robinsona somatyka przekładu - projekt rewaloryzacji idiosomatycznego impulsu w tłumaczeniu wobec społecznie utwierdzanego ideosomatycznego terroru. W ramach opracowanej na początku lat dziewięćdziesiątych somatycznej teorii przekładu proces tworzenia, czytania, tłumaczenia i czytania tłumaczenia pojmowany jest jako „seria reakcji somatycznych” („series of somatic responses”31). Kategorię klasycznie rozumianej ekwiwalencji Robinson zastępuje tezą o „ekwiwalencji somatycznej”, ekwiwalentnym odczuwaniu: „Ekwiwalencja pomiędzy słowem bądź wyrażeniem języka źródłowego oraz docelowego jest zawsze przede wszystkim somatyczna: dwa sformułowania odczuwa się tak samo" ${ }^{32}$. Istotnym mechanizmem tego czucia jest synestetyczne „obracanie słów na języku”33 podczas przekładowego polowania na cielesny równoważnik w języku przekładu, proprio- i interocepcyjne (wewnątrzcielesne) odczuwanie odpowiedniości wyrażeń językowych. Język, podobnie jak u Barthes’a, jest materią dotykalną oraz ożywioną: „potykamy się o słowa”" ${ }^{4}$, „łłowa mogą też pieścić, koić”35. Robinson wysuwa tezę o uniwersalności synestetycznego odczuwania języka: dla każdego z nas pismo ma zapach, mowa - smak; słowa nas dotykają, słowa nas bolą:

Słowa mają zapach, dla nas wszystkich: czujemy je tak wyraźnie jak je widzimy; smakujemy słowa, podobnie jak je słyszymy. Ponieważ jednak nasza kultura odwodzi nas od postrzegania języka w kategoriach wrażeń zmysłowych, te cielesne reakcje na słowa pozostają nieświadome, a zatem często uśpione - nie wykorzystujemy ich, nie pozwalamy im nami kierować. Odczuwamy słowa również taktylnie - możemy odczuć, że słowa nas osaczają, uderzają nas ${ }^{36}$.

Z Robinsonowskim rozpoznaniem powszechności tłumionej kulturowo synestezji językowej zgodziłby się Richard Cytowic, według którego synestezja jest uświadomionym trybem uniwersalnie międzyzmysłowej percepcji ${ }^{37}$, poddawanej standardowo kategoryzującej adiustacji mentalnej. Niemniej Robinson nie opisuje w swym projekcie percepcyjnej postaci synestezji - odczuwanie języka odnosi on bowiem bezpośrednio do znaczenia słów, do pojęć; czu-

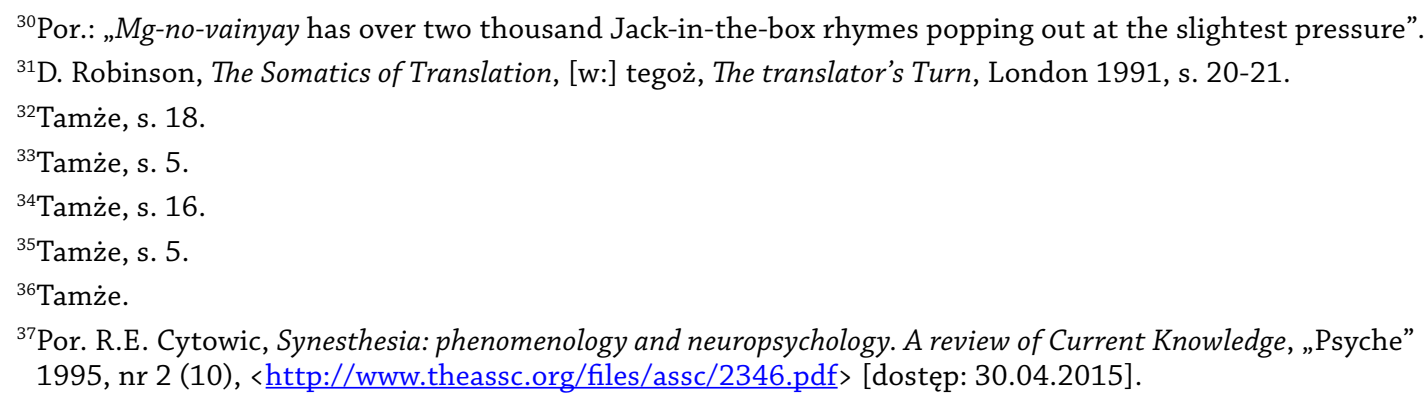


cie zagarnia tutaj to, co kognitywne, a ważnym mechanizmem okazuje się asocjacja. Dlatego też somatyczną teorię języka Robinsona nazwałabym raczej ideastezyjną (idea: pojęcie oraz aisthesis: czucie, a zatem postrzeganie pojęcia) niż synestetyczną (syn: razem, a więc: łączne postrzeganie). Somatyka Robinsona problematyzuje czucie pojęć i znaczeń, nie zaś czystej, asemantycznej materii języka.

Robinson apeluje o zaniechanie w przekładzie taktyk kontroli ciała (a więc o rozpoznanie i zawieszenie ideosomatycznego wymiaru przekładu - demaskację ciała w ideologii, ciała zinstytucjonalizowanego, społecznie utwierdzonego w somatycznym automatyzmie reakcji) na rzecz jego zindywidualizowanej eksploracji ${ }^{38}$. Udana translacja nie jest - w świetle somatyki przekładu Robinsona - wynikiem serii procedur intelektualnych, lecz owocem wrażliwości tłumacza na cielesne oddziaływanie języka ${ }^{39}$. Według autora ideosomatyczna „robotyzacja reakcji cielesnych [...] zasila zachodni mit czysto kognitywnej natury języka"40, który należy przezwyciężyć: język jest bowiem czuciem oscylującym pomiędzy determinantą społeczno-polityczną a autentyzmem idiosomatyki. Drogę powrotną do idiomatycznego doświadczania języka wskazuje sam ideastezyjny język i samo sensualne ciało.

W trzech przywołanych powyżej tekstach synestezja ukazuje się jako zasada przyjemności czytania oraz tłumaczenia. To właśnie międzyzmysłowe odczuwanie języka funduje instynkt tłumacza; intersensualność jest również istotną jakością czytelniczej wrażliwości. W krytyce oraz praktyce przekładu Nabokova, podobnie jak w translatologicznej koncepcji Douglasa Robinsona (The Somatics of Translation), to właśnie synestetycznie odczuwana materialność języka staje się kluczowym kryterium doboru leksykalnych oraz syntaktycznych środków w tłumaczeniu. W obu przypadkach synestezja okazuje się - mniej lub bardziej uświadomioną - zasadą językowego instynktu tłumacza. Intersensualny, cielesny kontakt z językiem objawia się zatem nie tylko w akcie twórczym, za który uważać należy również praktykę translatorską, ale także w (Barthes'owskim) odbiorze sztuki słownej oraz literaturoznawczej metarefleksji.

Czy zatem tego typu projekty i manifesty uwrażliwiają nas na pomijany i tłumiony, a przecież uniwersalny aspekt synestetycznego, somatycznego i przyjemnościowego doświadczania tkanki językowej, czy są jedynie projekcją całkowicie osobniczej idiosynkrazji percepcyjnej synestezji jako rzadkiej anomalii neurologicznej - na grunt teorii? Barthes zdaje się używać synestetycznej metafory jako markera ekscesu rozkoszy, zajmującej ciało poprzez erotyczny kontakt z językiem. Synestezja Nabokova jest jednocześnie trybem percepcji oraz kreacji funkcjonalizacja intersensualności jako miary ekwiwalencji językowej jest pochodną intersensualnego postrzegania. Wreszcie w translatorskiej refleksji Robinsona ideastezja staje się kluczowym elementem warsztatu tłumacza: efektem ostrożnej oraz pogłębionej introspekcji (czy raczej: intro-stezji) - procesu docierania do idiosomatycznego, kreatywnego odczuwania języka oraz jednoczesnego oporu wobec ideosomatycznego automatyzmu.

\footnotetext{
${ }^{38} \mathrm{D}$. Robinson, The Somatics of Translation, s. 34.

${ }^{39}$ Tamże, s. 17.

${ }^{40}$ Tamże, s. 29.
} 
Synestezja to strategia językowej przyjemności, stanowiącej somatyczny impuls obcowania z tekstem: pisania, czytania oraz tłumaczenia. Barthes, Nabokov oraz Robinson, ośmielający się ujawnić swoje skandalicznie przyjemne stosunki ze słowem, wskazują na synestezyjne odczuwanie języka jako źródło translatorskiej intuicji, czytelniczej wrażliwości, oraz - co nierozłączne - tekstualnej przyjemności, pojmowanej jako integralna składowa doświadczeniowego wymiaru lektury oraz przekładu. Synestezja jest bowiem idiosynkrazją w tym sensie, w jakim jest nią każde jednostkowe sensualno-somatyczne doświadczenie, rozpięte nieodmiennie pomiędzy przyjemnością a nieprzyjemnością. Jakkolwiek je pojmujemy, indywidualne doświadczenie ciała w języku pozostaje płodnym impulsem czytających, piszących oraz tłumaczących - Barthes, namiętny czytelnik Sade’a, Fouriera oraz Loyoli, pozostawił ponowoczesności „jedno z najpiękniejszych świadectw lektury jako zbliżenia, ze wszystkimi możliwymi konotacjami słowa" ${ }^{41}$. Radykalna erotyzacja dyskursu ${ }^{42}$, posługująca się wachlarzem strategii ucieleśniania tekstu, zbliżania tego, co tekstualne, do tego, co cielesne - m.in. poprzez synestezyjną hiperbolizację sensualnej materii języka - była projektem opozycyjnym wobec „mocnej” teorii:

Materialność pisma pojawiła się po to, by chronić „nieprzechodniości” języka literatury, a zarazem przywrócić jej idiomatyczność. Stała się mocnym sygnałem jednostkowości i zdarzeniowości. Była więc - jak powie nieco później Lyotard - swego rodzaju narzędziem oporu wobec wszelkiej totalitaryzacji - także i tej intelektualnej ${ }^{43}$.

W rewolucyjnych projektach eksponujących surową materialność języka - stanowiącą warunek ucieleśnienia i konsekwentnej erotyzacji tekstu - synestezja staje się nierzadko jednym z uprzywilejowanych chwytów retorycznych jako instrument cielesno-językowego zbliżenia. Synestezyjna poetyka lektury i przekładu zasadza się właśnie na wadze przyjemności tekstu: tekstu oryginału, tekstu przekładu i rozpiętej pomiędzy nimi inter- i intrajęzykowej gry dźwięków, barw, postaci, smaku i dotyku, woni.

\footnotetext{
${ }^{41}$ A. Burzyńska, Ciało $w$ bibliotece, s. 249.

${ }^{42}$ Por. tamże, s. 247.

${ }^{43}$ Tamże.
} 


\title{
SŁOWA KLUCZOWE:
}

\author{
przyjemność
}

materialność języka

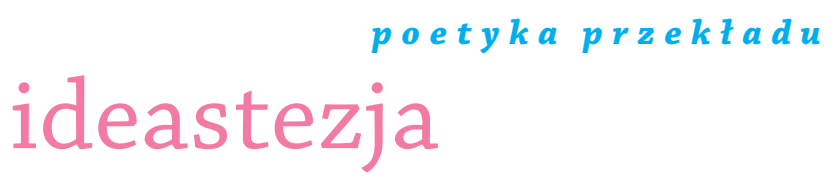

$V l$ a d i m i r $N$ a b o

materialność

s y n e s t e z ja

\section{PRZYJEMNOŚĆ TEKSTU}

przektad

materialność przekładu

ROLAND BARTHES

\section{Douglas Robinson}

\begin{abstract}
AbSTRAKT:
Opisując przyjemności oraz rozkosze czytania i pisania, Roland Barthes żongluje wielomodalnymi metaforami sensualnymi, angażując oraz splatając zmysły w synestezyjnym uścisku: słowa smakują, dotykają, przyprawiają o mdłości, rumienią się, podniecają. Tekst jest ciałem i czytanie jest cielesne. Doskonałym exemplum tak pojmowanej synestetycznej wrażliwości tekstu jest intersensualna proza Vladimira Nabokova. W krytyce oraz praktyce przekładu Nabokova, podobnie jak w translatologicznej koncepcji Douglasa Robinsona (The Somatics of Translation), to właśnie synestetycznie odczuwana materialność języka staje się kluczowym kryterium doboru leksykalnych oraz syntaktycznych środków w tłumaczeniu. W obu przypadkach synestezja okazuje się zasadą językowego instynktu tłumacza. Synestezja ukazuje się jako strategia językowej przyjemności, stanowiącej somatyczny impuls obcowania z tekstem. Barthes, Nabokov oraz Robinson wskazują na synestezyjne odczuwanie języka jako źródło translatorskiej intuicji, czytelniczej wrażliwości oraz tekstualnej przyjemności, pojmowanej jako integralna składowa doświadczeniowego wymiaru lektury oraz przekładu.
\end{abstract}

\section{NOTA O AUTORZE:}

Zuzanna Kozłowska - doktorantka Interdyscyplinarnych Studiów na Wydziale Filologii Polskiej i Klasycznej Uniwersytetu im. Adama Mickiewicza w Poznaniu, studentka językoznawstwa komputerowego, absolwentka filologii polskiej oraz romańskiej. Interesuje się humanistyką cyfrową, neuroestetyką oraz antropologią zmysłów i ciała jako nowymi horyzontami literaturoznawstwa. Bada synestezję literacką w polskiej poezji nowoczesnej. 